\title{
Analisis Kesulitan Peserta Didik dalam Pembelajaran Daring Matematika di Masa Pandemi COVID-19
}

\author{
Ryan Sulistyo ${ }^{1}$, Fitri Alyani ${ }^{2}$ \\ 1, 2 Prodi Pendidikan Matematika, Fakultas Keguruan dan Ilmu Pendidikan, Universitas Muhammadiyah Prof. Dr. Hamka, \\ Jl. Tanah Merdeka No.20, RT.11/RW.02, Rambutan, Kec. Ps. Rebo, Jakarta Timur, DKI Jakarta, Indonesia \\ mrryansulistyo@gmail.com
}

\begin{abstract}
Due to the Covid-19 pandemic, the Indonesian government has shifted face-to-face teaching and learning activities to online learning. The need for adaptation from teachers and students, so it does not rule out the possibility of finding difficulties in its implementation. This study aims to analyze the difficulties of learning mathematics online by students during the Covid-19 pandemic. The method used in this study is a mixed method. The subjects of this study were students from 3 equivalent high schools in the city of Bekasi, totaling 236 students. The instrument used is a questionnaire on the difficulty of learning mathematics online with 22 statements. The data obtained is processed using the Winsteps application. The results of interviews with students as an effort to describe the difficulties of students. The results of the study show that the indicators that most trigger student difficulties are technical constraints 0.15 logit, learning process difficulties -0.40 logit, and external constraints -0.41 logit. The conclusion of this study is that the difficulties that most trigger students are technical constraints regarding internet data quotas, difficulties in understanding online learning and being more interested in learning in class, and the lack of motivation by teachers during online learning.
\end{abstract}

Keywords: Analysis, Learning Difficulties, Online Learning, Covid-19.

\begin{abstract}
Abstrak
Akibat pandemi Covid-19 pemerintah Indonesia mengalihkan kegiatan belajar mengajar tatap muka menjadi pembelajaran daring. Butuhnya adaptasi dari guru dan peserta didik, sehingga tidak menutup kemungkinan mendapati kesulitan dalam pelaksanaannya. Penelitian ini bertujuan untuk menganalisis kesulitan pembelajaran daring matematika peserta didik di masa pandemic Covid-19. Metode yang digunakan dalam penelitian ini adalah mixed method. Subjek penelitian ini adalah peserta didik dari 3 sekolah SMA sederajat di kota Bekasi yang berjumlah 236 peserta didik. Instrumen yang digunakan yaitu kuisioner kesulitan pembelajaran daring matematika dengan 22 pernyataan. Data yang diperoleh diolah dengan menggunakan aplikasi Winsteps. Hasil wawancara dengan peserta didik sebagai upaya mendeskripsikan mengenai kesulitan peserta didik. Hasil dari penelitian menunjukkan data bahwa indikator yang paling memicu kesulitan peserta didik adalah kendala teknis 0,15 logit, kesulitan proses pembelajaran -0,40 logit, dan kendala eksternal -0,41 logit. Kesimpulan dari penelitian ini yaitu kesulitan yang paling memicu peserta didik adalah kendala teknis mengenai kuota data internet, kesulitan dalam memahami pembelajaran daring dan lebih tertarik belajar di kelas, serta kurangnya pemberian motivasi oleh guru pada saat pembelajaran daring.
\end{abstract}

Kata kunci: Analisis, Kesulitan Belajar, Pembelajaran Daring, Covid-19

Copyright (c) 2021 Ryan Sulistyo, Fitri Alyani

$\triangle$ Corresponding author: Fitri Alyani

Email Address: fitrialyani@uhamka.ac.id (Jl. Tanah Merdeka No.20, RT.11/RW.02, DKI Jakarta, Indonesia)

Received 10 July 2021, Accepted 06 Agustus 2021, Published 06 August 2021

\section{PENDAHULUAN}

Virus Covid-19 yang berasal dari kota Wuhan, China menggemparkan dunia pada akhir tahun 2019 (Liu et al., 2020). Virus menyebar pesat ke seantero negara yang tak luput juga negara Indonesia. Virus Covid-19 mulai bermutasi ke Indonesia pada bulan Maret 2020, sehingga pemerintah Indonesia dengan sigap membuat kebijakan stay at home untuk seluruh masyarakat Indonesia selaras dengan himbauan WHO (Amelia et al., 2020). Pembatasan social diberlakukan oleh pemerintah sebagai langkah dalam mengentikan penyebaran virus. Untuk mengendalikan penyebaran wabah, pemerintah nasional harus membuat langkah 
preventif yaitu social distancing, karantina wilayah, dan pembatasan pendidikan (Bourouiba, 2020). Pada 12 Maret 2020, di lima benua berbeda 46 negara telah menutup sekolah secara nasional (Huang et al., 2020). Dari kebijakan yang ditetapkan kementerian pendidikan di Indonesia berimbas kepada aktivitas pendidikan, sehingga wabah pandemi Covid-19 ini mengubah aktivitas pembelajaran dari tatap muka menjadi pembelajaran daring. (Simanjuntak et al., 2020)

Paradigma ini memaksa guru yang belum terbiasa mengajar secara daring kini harus terbiasa menggunakan berbagai metode pembelajaran daring dan menyampaikan materi kepada peserta didik melalui daring. (Abdullahi et al., 2020). Pasalnya terdapat perbedaan antara pembelajaran tatap muka dan pembelajaran daring, dimana peserta didik memiliki perangkat elektronik yang memadai (Simanjuntak et al., 2020). Selain itu, guru dan peserta didik harus bisa mengaplikasikan software untuk menunjang pembelajaran daring, seperti zoom meeting, google classroom, dan whatsapp. (Abdullahi et al., 2020)

Pembelajaran daring memudahkan peserta didik mengakses pembelajaran kapanpun dan dimanapun berada (Shukla et al., 2020). Kemudahan lain yang ditawarkan dalam pembelajaran daring, memudahkan peserta didik memperoleh informasi yang lebih mendalam melalui jejaring internet. (Hastini et al., 2020). Dengan belajar melalui daring peserta didik mendapatkan kemudahan dalam segi waktu, tempat, dan jarak. (Putria et al., 2020) Karena peralihan dari pembelajaran tatap muka ke pembelajaran daring, tidak menutup kemungkinan mendapati kesulitan dalam pelaksanaannya. Kesulitan yang dialami peserta didik dalam melaksanakan pembelajaran daring yaitu peserta didik belum mandirinya peserta didik dan cenderung menunggu instruksi dari guru, sebagian siswa belajar matematika dengan seperlunya, belum terbiasanya belajar matematika di depan layar laptop dalam waktu yang lama sehingga bosan dan sukar menerima pengajaran, terkendalanya oleh sinyal dan alat elektronik lainnya yang bisa menjatuhkan mood siswa dalam belajar dan siswa terkesan merasa terbebani dengan tugas yang diberikan oleh guru dan cenderung menyerah dengan hasil seadanya (Utami \& Cahyono, 2020). Adapun faktor penyebab kesulitan belajar matematika di antaranya abstraknya objek dan pola dalam matematika, terdapat banyak rumus, dan limitasi ruang interaksi yang terjadi antara guru dan peserta didik (Andriyansah et al., 2021). Mata pelajaran matematika terkenal sulit sehingga pandangan peserta didik terhadap matematika menganggap pelajaran yang sulit karena abstraknya objek dan banyaknya rumus yang digunakan akibatnya sulit untuk dimengerti dan dipahami oleh peserta didik (Utami \& Cahyono, 2020).

Dengan berbagai kondisi kesulitan yang dialami peserta didik selama pembelajaran daring pada mata pelajaran matematika, maka penelitian ini bertujuan untuk menganalisis kesulitan pembelajaran daring matematika dilihat dengan tingkatan kesulitan yang paling memicu peserta didik dalam proses pembelajaran daring. Dengan harapan penelitian ini sebagai bahan referensi untuk pendidik dalam memahami dan memerhatikan kesulitan peserta didik.

\section{METODE}

Penelitian ini menggunakan metode gabungan (mixed method). Penelitian ini dilakukan dengan pengumpulan dua macam data kuantitatif dan kualitatif dengan rumusan dan waktu yang sama (Sugiyono, 
2008). Untuk melihat kesulitan pembelajaran daring peserta didik dilakukan analisis instumen dengan pendekatan kuantitatif, kemudian untuk mendapatkan informasi yang lebih komprehensif dilakukan wawancara kepada dua peserta didik sesuai dengan tingkatan kesulitan yang didapatkan dengan pendekatan kualitatif deskriptif. Subjek pada penelitian ini melibatkan peserta didik SMA/MA sederajat di kota Bekasi yang melibatkan 236 peserta didik di 3 sekolah. Penelitian ini menggunakan tiga teknik pengumpulan data yaitu kuisioner, wawancara, dan dokumentasi. Teknik pengumpulan data menggunakan kuisioner dalam bentuk google form. Kuisioner berisi 22 butir item pernyataan yang terdiri dari 3 indikator kesulitan pembelajaran daring peserta didik yang di adaptasi dari artikel berjudul Study At Home: Analisis Kesulitan Belajar Matematika Pada Proses Pembelajaran Daring (Utami \& Cahyono, 2020). Skala likert yang digunakan dengan 4 pilihan Sangat Setuju (SS), Setuju (S), Tidak Setuju (TS), dan Sangat Tidak Setuju (STS) (Sugiyono, 2008).

Analisis data dilakukan dengan menggunakan Model Rasch dengan berbantuan software Winsteps. Model Rasch menyajikan analisis item pada tingkatan masing - masing item dan konsistensi jawaban dari responden (Sumintono \& Widhiarso, 2015). Untuk melihat yang paling memicu kesulitan peserta didik pada masing - masing indikator yaitu dari rata - rata nilai logit tertinggi.

Tabel 1. Demografis Responden

\begin{tabular}{|c|c|c|c|}
\hline Demografi & Keterangan & Label & Persentase $(\%)$ \\
\hline \multirow{2}{*}{ Jenis Kelamin } & Laki - laki & $\mathrm{L}$ & $49,20 \%$ \\
\hline & Perempuan & $\mathrm{P}$ & $50,80 \%$ \\
\hline \multirow{2}{*}{ Kelas } & $\mathrm{X} / 10$ & A & $72,90 \%$ \\
\hline & $\mathrm{XI} / 11$ & $\mathrm{~B}$ & $27,10 \%$ \\
\hline \multirow{6}{*}{ Jurusan } & IPA & $\mathrm{C}$ & $53 \%$ \\
\hline & IPS & $\mathrm{D}$ & $13,10 \%$ \\
\hline & TKR & $\mathrm{E}$ & $9,32 \%$ \\
\hline & TITL & $\mathrm{F}$ & $7,20 \%$ \\
\hline & TAV & $\mathrm{G}$ & $2,54 \%$ \\
\hline & RPL & $\mathrm{H}$ & $6,36 \%$ \\
\hline \multirow{3}{*}{ Asal Sekolah } & SMAN 18 Bekasi & $\mathrm{I}$ & $38,60 \%$ \\
\hline & SMA Muhammadiyah 9 Bekasi & $\mathrm{J}$ & $33,10 \%$ \\
\hline & SMK Taruna Bangsa Bekasi & $\mathrm{K}$ & $28,40 \%$ \\
\hline \multirow{3}{*}{$\begin{array}{c}\text { Alat elektronik yang } \\
\text { digunakan }\end{array}$} & Handphone/tablet & $\mathrm{M}$ & $91,10 \%$ \\
\hline & Laptop & $\mathrm{N}$ & $8,47 \%$ \\
\hline & Komputer/PC & $\mathrm{O}$ & $0,42 \%$ \\
\hline \multirow{3}{*}{ Milik } & Pribadi & Q & $94,90 \%$ \\
\hline & Orang tua & $\mathrm{R}$ & $4,66 \%$ \\
\hline & Kakak/Adik & $\mathrm{S}$ & $0,42 \%$ \\
\hline
\end{tabular}

Kemudian dilanjutkan dengan wawancara kepada peserta didik yang mewakili tingkatan kesulitan pembelajaran daring matematika berdasarkan nilai separation dapat dilihat pada tabel 5. Dilakukan wawancara dengan dua peserta didik yang mewakili tingkatan kesulitan. Metode wawancara yang digunakan peneliti yaitu metode wawancara semi struktur dengan tujuan untuk lebih mendalami pertanyaan 
Analisis Kesulitan Peserta Didik dalam Pembelajaran Daring Matematika di Masa Pandemi COVID-19, Ryan Sulistyo, Fitri Alyani

- pertanyaan yang telah peneliti buat. Sehingga informasi yang didapatkan dari peserta didik lebih komprehensif dan sesuai dengan kesulitan yang dialami.

\section{HASIL DAN DISKUSI}

\section{Data Hasil Kuisioner Kesulitan Pada Proses Pembalajaran Daring Matematika}

Studi kuantitatif dihitung berbantuan aplikasi Winsteps. Model Rasch menyajikan data secara keseluruhan terkait kualitas instrumen, kualitas responden dan kualitas hubungan antara responden dan item. Data dalam tabel summary statistic pada tabel 2 menyajikan kualitas responden, kualitas item, dan kualitas hubungan responden dan item. Rata - rata yang didapat dalam kualitas kemampuan responden (person measure) sebesar -0,25 kurang dari 0,0 logit menunjukkan bahwa responden cenderung tidak menyetujui item. (Sumintono \& Widhiarso, 2014). Kemudian nilai person reliability dan item reliability sebesar 0,47 dan 0,98. Hal tersebut menunjukkan bahwa konsistensi responden dalam menjawab item lemah sementara kualitas butir pernyataan instrumen berkualitas/istimewa. (Sumintono \& Widhiarso, 2014). Adapun nilai alpha cronbach sebesar 0,53. menyatakan bahwa hubungan interaksi antara responden dengan item dalam instrument adalah jelek (Sumintono \& Widhiarso, 2015).

Tabel 2. Summary Statistics

\begin{tabular}{|c|c|c|c|c|c|}
\hline & Mean & SD & $\begin{array}{c}\text { Separation } \\
\text { Index }\end{array}$ & Reliability & Cronbach \\
\hline Person & $-0,25$ & 0,28 & 0,95 & 0,47 & \multirow{2}{*}{0,53} \\
\hline Item & 0.00 & 0,67 & 7,80 & 0,98 & \\
\hline
\end{tabular}

Kesesuaian butir soal (item fit) dan kesesuaian responden dalam menjawab pernyataan (person fit) dapat dilihat pada tabel 3. Secara keseluruhan item pernyataan dalam instrument dapat digunakan (item fit). Karena nilai mean square dan z-standard memenuhi kriteria meskipun nilai point measure correlation terlalu tinggi. Sementara dengan person fit, secara keseluruhan person fit dapat digunakan karena nilai mean square dan nilai z-standard memenuhi kriteria meskipun point measure correlation terlalu rendah.

Tabel 3. Kualitas Kesesuaian Person dan Item

\begin{tabular}{|c|c|c|c|}
\hline & MNSQ & ZSTD & Correlation \\
\hline Person & 1,00 & $-0,20$ & 1,00 \\
\hline Item & 1,00 & $-0,03$ & $-1,00$ \\
\hline
\end{tabular}

Kemudian hasil penelitian lain terkait tingkatan kesulitan pembelajaran daring matematika yang dirasakan peserta didik tingkat SMA disajikan dalam person map. Pada gambar 1 dibawah menyajikan tingkat kesulitan belajar matematika peserta didik melalui pembelajaran daring. 


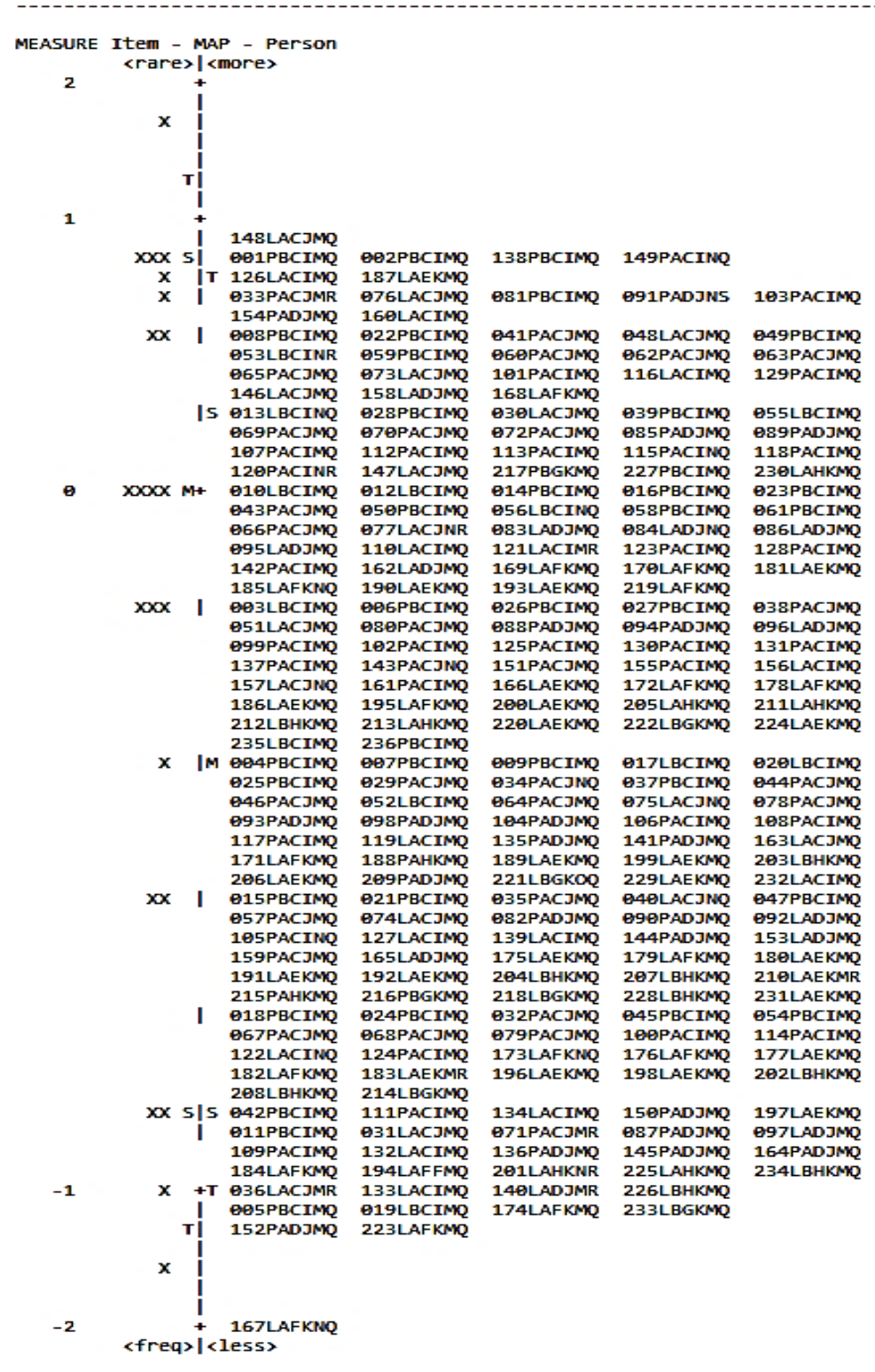

Gambar 1. Person Map Kesulitan Pembelajaran Daring

Setelah melihat urutan kesulitan berdasarkan person map. Berdasarkan nilai separation pada tabel 2 diperoleh dua kelompok tingkatan kesulitan peserta didik. Dapat dilihat pada tabel 5 persentase peserta didik yang mengalami tingkat kesulitan dalam pembelajaran daring matematika. Persentase tersebut disajikan melalui tabel dan dapat terlihat bahwa dari responden yang mengalami tingkat kesulitan tinggi memiliki persentase $22,03 \%$ dan responden yang mengalami tingkat kesulitan rendah adalah $77,97 \%$.

Tabel 4. Kelompok Responden

\begin{tabular}{|c|c|c|}
\hline $\begin{array}{c}\text { Tingkat Kesulitan } \\
\text { Peserta didik }\end{array}$ & Frekuensi & Persentase \\
\hline Tinggi & 52 Responden & $22,03 \%$ \\
\hline Rendah & 184 Responden & $77,97 \%$ \\
\hline
\end{tabular}

Tabel 5 menunjukkan bahwa rata - rata logit kesulitan teknis bernilai 0,15 dengan standar deviasi 
sebesar 1,18. Sementara rata - rata logit kesulitan proses pembelajaran daring bernilai $-0,40$ dengan nilai standar deviasi sebesar 0,51. Sedangkan rata - rata logit kesulitan eksternal bernilai -0,41 dengan standar deviasi sebesar 0,84. Dilihat dari hasil kuisioner diatas bahwa rata - rata pada indikator 1 (kesulitan teknis) lebih tinggi dari indikator 2 (kesulitan proses pembelajaran) dan indikator 3 (kesulitan eksternal).

Tabel 5. Hasil Kuisioner Keseluruhan Indikator

\begin{tabular}{|c|c|c|c|c|c|c|}
\hline & \multicolumn{2}{|c|}{$\begin{array}{c}\text { Indikator 1 } \\
\text { (Kesulitan Teknis) }\end{array}$} & \multicolumn{2}{c|}{$\begin{array}{c}\text { Indikator 2 } \\
\text { (Kesulitan Proses) }\end{array}$} & \multicolumn{2}{c|}{$\begin{array}{c}\text { Indikator 3 } \\
\text { (Kesulitan Eksternal) }\end{array}$} \\
\cline { 2 - 7 } & $\begin{array}{c}\text { Item } \\
\text { count }\end{array}$ & Measure & $\begin{array}{c}\text { Item } \\
\text { count }\end{array}$ & Measure & $\begin{array}{c}\text { Item } \\
\text { count }\end{array}$ & Measure \\
\hline Mean & 5 & 0,15 & 12 & $-0,40$ & 5 & $-0,41$ \\
\hline P.SD & 0 & 1,18 & 0 & 0,51 & 0 & 0,84 \\
\hline Max. & 5 & 3,43 & 12 & 0,98 & 5 & 1,99 \\
\hline Min. & 5 & $-2,57$ & 12 & $-1,91$ & 5 & $-2,68$ \\
\hline
\end{tabular}

Berdasarkan rata - rata masing - masing indikator yang paling memicu kesulitan peserta didik dalam melaksanakan pembelajaran daring matematika yaitu kendala teknis dengan nilai logit sebesar 0,15 . Selaras dengan penelitian Utami (Utami \& Cahyono, 2020) yang menyatakan kesulitan yang paling sering dirasakan oleh peserta didik adalah kesulitan teknis dan ketidakmampuan dalam pembelajaran daring.

\section{Indikator Kendala Teknis}

Tabel 6. Item Measure Indikator Kendala Teknis

\begin{tabular}{|c|c|c|c|c|c|c|c|c|c|}
\hline \multirow{2}{*}{ Item } & Total & \multicolumn{2}{|c|}{ Model } & \multicolumn{2}{c|}{ Infit } & \multicolumn{2}{c|}{ Outfit } & \multicolumn{2}{c|}{ Pt Measure-Al } \\
\cline { 3 - 9 } & Score & MEASURE & S.E. & MNSQ & ZSTD & MNSQ & ZSTD & CORR. & EXP. \\
\hline I2 & 483 & 1.08 & .10 & .83 & -2.01 & .83 & -2.01 & .70 & .62 \\
\hline I1 & 538 & .59 & .09 & .85 & -1.82 & .84 & -1.96 & .64 & .63 \\
\hline I5 & 573 & .28 & .09 & .96 & -.47 & .96 & -.46 & .66 & .63 \\
\hline I4 & 653 & -.40 & .09 & 1.26 & 2.86 & 1.29 & 3.01 & .55 & .62 \\
\hline I3 & 773 & -1.55 & .10 & 1.08 & .84 & 1.11 & .98 & .54 & .58 \\
\hline MEAN & 604.0 & .00 & .10 & 1.00 & -.1 & 1.00 & -.1 & & \\
\hline P.SD & 100.9 & .91 & .00 & .16 & 1.8 & .18 & 1.9 & & \\
\hline
\end{tabular}

Dari tabel 7 dapat dilihat item pernyataan yang paling memicu kesulitan peserta didik adalah item pernyataan nomor dua yang menyatakan "terkadang kuota data menjadi salah satu kendala untuk melaksanakan pembelajaran daring".

\section{Indikator Kesulitan Proses Pembelajaran}

Tabel 7. Item Measure Indikator Kesulitan Proses Pembelajaran

\begin{tabular}{|c|c|c|c|c|c|c|c|c|c|}
\hline \multirow{2}{*}{ Item } & Total & \multicolumn{2}{|c|}{ Model } & \multicolumn{2}{c|}{ Infit } & \multicolumn{2}{c|}{ Outfit } & \multicolumn{2}{c|}{ Ptmeasure-Al } \\
\cline { 3 - 10 } & Score & MEASURE & S.E. & MNSQ & ZSTD & MNSQ & ZSTD & CORR. & EXP. \\
\hline I7 & 342 & 1.61 & .11 & .99 & -.06 & .96 & -.32 & .23 & .29 \\
\hline I10 & 452 & .58 & .09 & .67 & -4.53 & .66 & -4.65 & .57 & .35 \\
\hline I14 & 469 & .45 & .09 & .88 & -1.53 & .87 & -1.62 & .62 & .36 \\
\hline I8 & 499 & .24 & .08 & .89 & -1.39 & .88 & -1.45 & .52 & .37 \\
\hline I16 & 499 & .24 & .08 & 1.12 & 1.44 & 1.13 & 1.59 & .07 & .37 \\
\hline I13 & 545 & -.08 & .08 & .98 & -.22 & 1.00 & -.02 & .57 & .37 \\
\hline
\end{tabular}




\begin{tabular}{|c|c|c|c|c|c|c|c|c|c|}
$\mathrm{I} 17$ & 569 & -.25 & .08 & 1.21 & 2.49 & 1.24 & 2.78 & .04 & .38 \\
\hline $\mathrm{I} 15$ & 576 & -.29 & .08 & .92 & -.99 & .92 & -.96 & .57 & .38 \\
\hline $\mathrm{I} 6$ & 591 & -.40 & .08 & .84 & -2.03 & .84 & -2.03 & .59 & .38 \\
\hline $\mathrm{I} 12$ & 616 & -.57 & .08 & .89 & -1.41 & .89 & -1.44 & .53 & .37 \\
\hline $\mathrm{I} 9$ & 621 & -.60 & .08 & 1.31 & 3.47 & 1.31 & 3.46 & .16 & .37 \\
\hline $\mathrm{I} 11$ & 669 & -.93 & .08 & 1.23 & 2.67 & 1.30 & 3.34 & -.22 & .37 \\
\hline MEAN & 537.3 & .00 & .09 & .99 & -.2 & 1.00 & -.1 & & \\
\hline P.SD & 86.1 & .65 & .01 & .18 & 2.2 & .19 & 2.4 & & \\
\hline
\end{tabular}

Dari tabel 8 dapat dilihat item pernyataan yang paling memicu kesulitan peserta didik adalah item pernyataan nomor tujuh yang menyatakan bahwa "saya lebih tertarik belajar di kelas karena saya dapat berinteraksi langsung dengan guru".

Indikator Kesulitan Eksternal

Tabel 8. Item Measure Indikator Kendala Eksternal

\begin{tabular}{|c|c|c|c|c|c|c|c|c|c|}
\hline \multirow{2}{*}{ Item } & Total & \multicolumn{2}{|c|}{ Model } & \multicolumn{2}{c|}{ Infit } & \multicolumn{2}{c|}{ Outfit } & \multicolumn{2}{c|}{ Ptmeasure-Al } \\
\cline { 3 - 10 } & SCORE & MEASURE & S.E. & MNSQ & ZSTD & MNSQ & ZSTD & CORR. & EXP. \\
\hline $\mathrm{I} 22$ & 440 & .87 & .10 & .92 & -.86 & .96 & -.39 & .48 & .46 \\
\hline $\mathrm{I} 18$ & 450 & .77 & .10 & 1.32 & 3.21 & 1.32 & 3.24 & .25 & .46 \\
\hline $\mathrm{I} 21$ & 538 & -.07 & .09 & .84 & -1.88 & .85 & -1.79 & .68 & .49 \\
\hline $\mathrm{I} 20$ & 539 & -.08 & .09 & .69 & -3.88 & .71 & -3.66 & .57 & .49 \\
\hline $\mathrm{I} 19$ & 707 & -1.48 & .09 & 1.20 & 2.32 & 1.19 & 2.22 & .45 & .51 \\
\hline MEAN & 534.8 & .00 & .10 & .99 & -.2 & 1.01 & -.1 & & \\
\hline P.SD & 95.8 & .84 & .00 & .23 & 2.6 & .22 & 2.5 & & \\
\hline
\end{tabular}

Dari tabel 9 dapat dilihat item pernyataan yang paling memicu di dalam indikator kendala eksternal adalah item pertanyaan nomor dua puluh dua yang menyatakan bahwa "guru matematika tidak memberikan motivasi dalam pembelajaran daring”.

\section{Hasil Wawancara}

Hasil wawancara untuk mendeskripsikan mengenai kesulitan yang dialami peserta didik dalam proses pembelajaran daring matematika sebagai bahan pendekatan studi kualitatif deskriptif. Responden penelitian ditentukan berdasarkan hasil separation dapat dilihat pada tabel 5. Berikut hasil percakapan wawancara dengan peserta didik. Student 1 dengan tingkat kesulitan peserta didik rendah dan Student 2 dengan tingkat kesulitan peserta didik yang tinggi.

Berikut hasil percakapan antara peneliti dan peserta didik.

Researcher: Bagaimana proses pembelajaran matematika secara daring?

Student 1: Pemahaman materi yang masuk kurang, dikarenakan kita sendiri diasupin latihan soal terus walaupun sesekali ada zoom meeting ada penjelasan materi, belajar langsung di kelas beda cara memahami materinya dengan belajar daring. Aplikasi zoom meeting khusus untuk pembahasan materidan untuk pengumpulan latihan soal lewat google classroom. 
Analisis Kesulitan Peserta Didik dalam Pembelajaran Daring Matematika di Masa Pandemi COVID-19, Ryan Sulistyo, Fitri Alyani

Student 2: Yang dijalanin selama pembelajaran daring ini, kadang ada zoom meeting buat ngebahas materi yang gangerti bisa nanya gurunya via whatsapp, terus dikasih tugas sama latihan dikumpulin di google classroom dan diberikan batas waktunya sama gurunya.

Researcher: Apakah pembelajaran matematika secara daring dapat memudahkan anda dalam memahami pembelajaran matematika?

Student 1: Pemahaman materi selama belajar dirumah kurang, beda seperti di sekolah, selama kelas 11 ini materi matematika yang dapat dipahami cuma ada 1 bab dari semua bab yang dipelajari. Kosong banget kak materi yang dipahamin.

Student 2: Sulit kak pahamin materi matematika kalau belajar daring gini, ujung ujungnya searching soal di google itupun juga kadang - kadang nanya sama temen - temen yang udah selesain tugas yang dikasih guru. Itu baru tugas matematika ajah kak, belum tugas maple lainnya.

Researcher: Apa saja kendala teknis yang dialami selama proses pembelajaran matematika secara daring? Misal kendala sinyal, kuota, atau hal lainnya.

Student 1: Yaa, dirumah ada wifi jadinya tidak terlalu berpengaruh kak, terus alhamdulillah dapet dari pemerintah jadi buat kuota tidak terlalu digunakan.

Student 2: Kendala kuota internet sih kak, meskipun udah dikasih sama pemerintah tapi kalo buat belajar dan harus buka youtube kemudian zoom meeting butuh kuota yang banyak kadang suka abis dan harus beli lagi.

Researcher: Apa saja kesulitan yang dialami selama proses pembelajaran matematika secara daring? Serta bagaimana cara anda mengatasinya?

Student 1: Selama proses pembelajaran daring kak, kesulitan memahami materi kak, materi masih kelas 10 masih mudah, masuk belajar daring di kelas 11 tidak paham sama sekali, kadang guru bahas materi di zoom juga bingung nangkep materinya.

Student 2: Kesulitan nya lebih ke harus belajar mandiri aja sih kak, biasanya kan kalo dikelas bisa nanya temen, nah kalo belajar dirumah ujung - ujungnya nyari jawaban di google.

Researcher: Bagaimana peran guru matematika dan wali kelas dalam proses pembelajaran matematika secara daring?

Student 1: Guru makin kesini makin banyak memberikan tugas, dijalanin aja kak sampai masuk sekolah tatap muka.

Student 2: Guru biasanya hanya memberikan materi lewat modul ppt atau ebook kita kemudian mengerjakan latihan soal.

Researcher: Bagaimana peran orangtua anda dalam proses pembelajaran matematika secara daring?

Student 1: Terbantu dengan peran orang tua yang selalu ngasih motivasi ke saya, saya juga diikutkan ke bimbel online ruang guru kak, sebagai bahan tambahan belajar.

Student 2: Orang tua saya kerja dua duanya kak, kalau belajar daring tidak pernah didampingi, hanya saja terkadang ditanyain orang tua sudah mengumpulkan tugas atau belum, karena ada grup bareng sama orang tua. 
Dari percakapan dengan peserta didik, mereka menyatakan bahwa jaringan internet yang terkadang tidak stabil dan kuota internet yang terbatas menjadi kendala dalam pembelajaran daring matematika. Disebabkan karena ada sebagian peserta didik yang belum memiliki fasilitas wifi di rumahnya sehingga kadang terkendala kuota internet yang habis. Selaras dengan temuan penelitian oleh (Simanjuntak et al., 2020) kesulitan yang dialami oleh peserta didik adalah salah satunya ketidakmampuan peserta didik untuk membeli kuota internet.

Terbiasa dengan pembelajaran tatap muka di sekolah ketika beralih ke pembelajaran daring, ternyata mereka mengalami kesulitan beradaptasi dalam memahami materi matematika. Selaras dengan temuan (Hebebci et al., 2020) yang menyatakan bahwa peserta didik belum terbiasa dalam menjalankan proses pembelajaran daring. Kemudian memahami materi dalam pembelajaran daring menjadi kesulitan mereka. Temuan penelitian oleh (Abdullahi et al., 2020) didapati tantangan dalam pembelajaran daring yaitu peserta didik di Nigeria kesulitan dalam memahami dan menyelesaikan soal - soal matematika selama pembelajaran daring. Penjelasan materi dari guru yang hanya sesekali saja melalui aplikasi zoom meeting, selebihnya mereka diberikan tugas dan latihan soal melalui aplikasi google classroom. Mereka merasakan beban tugas yang diberikan oleh guru lebih banyak daripada belajar tatap muka. Kemudian tugas dan latihan soal dikumpulkan dengan waktu yang ditentukan oleh guru membuat mereka merasa kesulitan dalam mengumpulkannya. Temuan yang sama selaras dengan penelitian (Abdullahi et al., 2020) menyatakan bahwa peserta didik juga mengalami kesulitan dalam mengumpulkan tugas matematika secara daring. Peran orang tua dan guru juga sangat penting, mereka menjelaskan bahwa orang tua mereka sibuk dengan pekerjaannya. Akibatnya peserta didik tidak memperoleh pendampingan dari orang tua dalam pembelajaran daring (Abdullahi et al., 2020).

\section{KESIMPULAN}

Berdasarkan analisis hasil penelitian diatas dapat disimpulkan bahwa kesulitan peserta didik dalam melakukan pembelajaran daring matematika pada masing - masing indikator dengan kesulitan paling tinggi yaitu indikator kendala teknis. Dengan perolehan rata - rata nilai pada indikator kendala teknis sebesar 0,15 logit. Kemudian dari item masing - masing per indikator yang paling memicu kesulitan peserta didik adalah terkadang kuota data menjadi salah satu kendala untuk melaksanakan pembelajaran daring, saya lebih tertarik belajar di kelas karena saya dapat berinteraksi langsung dengan guru, dan guru matematika tidak memberikan motivasi dalam pembelajaran daring. Dari hasil penelitian ini kiranya dapat dijadikan sebagai bahan referensi dan studi lebih lanjut mengenai kesulitan - kesulitan yang dialami peserta didik dalam pembelajaran daring khususnya materi matematika.

\section{REFERENSI}

Abdullahi, U., Sirajo, M., Saidu, Y., \& Bello, U. (2020). Stay-At-Home Order and Challenges of Online Learning Mathematics during Covid-19 Case in Nigeria. Journal of Research \& Method in Education, 10(4), 10-17. https://doi.org/10.9790/7388-1004061017 
Amelia, R., Kadarisma, G., Fitriani, N., \& Ahmadi, Y. (2020). The effect of online mathematics learning on junior high school mathematic resilience during COVID-19 pandemic. Journal of Physics: Conference Series, 1657(1). https://doi.org/10.1088/1742-6596/1657/1/012011

Andriyansah, R., Nurhidayati, A., Nataliasari, D., \& Rahmin, S. (2021). Kesulitan Pembelajaran Daring Matematika Saat Pandemi COVID-19 Pada Siswa SMP Kelas VIII. 3(1).

Bourouiba, L. (2020). Turbulent Gas Clouds and Respiratory Pathogen Emissions: Potential Implications for Reducing Transmission of COVID-19. JAMA - Journal of the American Medical Association, 323(18), 1837-1838. https://doi.org/10.1001/jama.2020.4756

Hastini, L. Y., Fahmi, R., \& Lukito, H. (2020). Apakah Pembelajaran Menggunakan Teknologi dapat Meningkatkan Literasi Manusia pada Generasi Z di Indonesia? Jurnal Manajemen Informatika (JAMIKA), 10(1), 12-28. https://doi.org/10.34010/jamika.v10i1.2678

Hebebci, M. T., Bertiz, Y., \& Alan, S. (2020). Investigation of Views of Students and Teachers on Distance Education Practices during the Coronavirus (COVID-19) Pandemic. International Journal of Technology in Education and Science, 4(4), 267-282. https://doi.org/10.46328/ijtes.v4i4.113

Huang, R. H., Liu, D. J., Tlili, A., Yang, J. F., \& Wang, H. H. (2020). Handbook on facilitating flexible learning during educational disruption: The Chinese experience in maintaining undisrupted learning in COVID-19 Outbreak. Smart Learning Institute of Beijing Normal University UNESCO, March, 154. https://iite.unesco.org/news/handbook-on-facilitating-flexible-learning-during-educationaldisruption/

Liu, J., Liao, X., Qian, S., Yuan, J., Wang, F., Liu, Y., Wang, Z., Wang, F. S., Liu, L., \& Zhang, Z. (2020). Community transmission of severe acute respiratory syndrome Coronavirus 2, Shenzhen, China, 2020. Emerging Infectious Diseases, 26(6), 1320-1323. https://doi.org/10.3201/eid2606.200239

Putria, H., Maula, L. H., \& Uswatun, D. A. (2020). Analisis Proses Pembelajaran dalam Jaringan (DARING) Masa Pandemi Covid- 19 Pada Guru Sekolah Dasar. Jurnal Basicedu, 4(4), 861-870. https://doi.org/10.31004/basicedu.v4i4.460

Shukla, T., Dosaya, D., Nirban, V. S., \& Vavilala, M. P. (2020). Factors extraction of effective teachinglearning in online and conventional classrooms. International Journal of Information and Education Technology, 10(6), 422-427. https://doi.org/10.18178/ijiet.2020.10.6.1401

Simanjuntak, D. R., Ritonga, M. N., \& Harahap, M. S. (2020). ANALISIS KESULITAN BELAJAR SISWA MELAKSANAKAN PEMBELAJARAN SECARA DARING SELAMA MASA PANDEMI COVID-19 Oleh. Mathematic Education Journal)MathEdu, 3(3), 142-146. http://journal.ipts.ac.id/index.php/

Sugiyono. (2008). Metode Penelitian Kualitatif dan Pembelajaran. In Metode Penelitian Kuantitatif, Kualitatif dan R\&D. Bandung:Alfabeta. Alfabeta.

Sumintono, B., \& Widhiarso, W. (2015). Aplikasi Model Rasch Untuk Penelitian Ilmu-Ilmu Sosial. Edisi Ke-2. Cimahi (Bambang Trim (ed.)). Trim Komunikata Publishing House. http://eprints.um.edu.my/11413/ 
Utami, Y. P., \& Cahyono, D. A. D. (2020). Study At Home: Analisis Kesulitan Belajar Matematika Pada Proses Pembelajaran Daring. Jurnal Ilmiah Matematika Realistik, 1(1), 20-26. https://doi.org/10.33365/ji-mr.v1i1.252 